\title{
FACTORS AFFECTING THE COLLABORATION IN SUPPLY CHAIN OF MECHANICAL ENTERPRISES IN VIETNAM
}

\author{
Luu Tien Dung \\ Department of Business Administration - International Economics, Lac Hong \\ University, No. 10 Huynh Van Nghe Street, Bien Hoa City, Dong Nai Province, \\ Vietnam
}

\begin{abstract}
In the context of international economic integration, enterprises need to participate in the global supply chain to take advantage of assets, talents and other capability. Base on the Structure Equation Model (SEM-PLS) using primary data collected from 205 mechanical enterprises in Vietnam, the research result shows that there are nine direct factors affecting the collaboration in supply chain including: (i) trust; (ii) power; (iii) maturity; (iv) frequency; (v) distance; (vi) culture; (vii) strategy; (viii) policy; (ix) commitment. Results of the research give strong evidences for policy makers and enterprises for management the supply chain collaboration in mechanical sector in particular and other sectors in general as well as its contribution to literature review of supply chain management.
\end{abstract}

\section{KEYWORDS}

Knowledge Management; Mechanical sector; Supply chain collaboration; Structure Equation Model (SEM-PLS); Vietnam

\section{INTRODUCTION}

Under strong pressure from the international economic integration, Vietnam mechanical enterprises have to locate, restructure the business activities towards improving competitiveness and value added base on the construction and consolidation of the supply chain will play a role as a key strategy. Supply chain is a wide network, consisting of many subjects and many complicated relationships including many independent business organizations Therefore, focusing on administratiion of the collaboration relationship in the chain had become one of the most important matter that both the researchers and executor pay attention to. A lot of science research has proved the influence of creating and maintaining the members' relationship through collaboration in the chain affects its effect. Therefore, building collaboration relationship is necessary to improve the business efficiency in the supply chain.

The process of free trade and international economic integration helps Vietnam to become one of the potential places to invest. Vietnam is actively joining AEC, TPP, FTA with the Customs Union of Russia-Belarus-Kazakhstan, EVFTA and others. This is the key for Vietnam enterprises to join in the global supply chain. Vietnam's goal is to become a modern industry country by 2020, therefore accelerating the development of mechanical industry is an important task under the decision No. 186/2002/QĐ-TTg dated 26/12/2002 of the government which approved the development strategy of Vietnam mechanical industry to 2010, vision to 2020 . However, according to VAMI, current mechanical industry is only meeting about $35-40 \%$ of the domestic demands. The solution for the development of mechanical industry becomes critical 
and challenging for Vietnam enterprises today. In order to have the sustainable development for mechanical industry, aside from boosting the association and connection of companies, the mechanical enterprises have to find a way to approach the world market by becoming a supply place in the global chain. Setting up a suitable supply chain is a vital matter of each enterprise and industry, however, the matter of identifying the entities within the supply chain and make the entities to cooperate more with each other is a must for a sustainable development of the enterprises.

This article focuses on making clearance factors that affecting the supply chain collaboration of mechanical enterprises in Vietnam base on the Structure Equation Model (SEM-PLS) using data collected from 205 mechanical enterprises in the Southeast region, one of the leading area in industrial development, especially in mechanical industry in Vietnam that including Ho Chi Minh City, Dong Nai and Binh Duong province. The research includes four parts: section 2 states the literature review, section 3 explains the applied research methods and study hypotheses and section 4 presents the results and discussion.

\section{LITERATURE REVIEW}

\subsection{The basic problems of supply chain collaboration}

\subsubsection{Supply chain collaboration}

Supply chain collaboration (SCC) is increasingly important in organizations because of its contributions to success of supply chain management and organization competiveness in the global economy. In supply chain, partnerships allow members of the system to achieve the set out objectives and meet the expectations of the consumers in the end (Samaddar et al., 2006). In reality, the establishment of a perspective on partnerships is a strategic decision by the common goals. According to Joffre and Koenig (1992) the coordination of the process of product supply is the prerequisite to develop between the owner of the resources as well as the efforts of the relationship. Perspectives of cooperation in relation to exchange are one of the effective means to develop and control or reduce the competitiveness among the subject. Furthermore, the partnership provides members in the distributed system with efforts to achieve the firm objectives, improvement of efficiency in the relations and improve the ability to provide and serve the customers (Vereecke and Muylle, 2006; Whipple and Russell, 2007).

Supply chain collaboration is widely studied from many different points of view sources and collaborative concepts began to be widespread in the areas of supply chain (SC) in the mid-1990s (Barratt, 2004). Collaboration is defined as a cooperation of two or more members base on working together to create a competitive advantage through information sharing, joint decision making, and sharing the benefits from greater profits by satisfying the customer needs than acting alone (Simatupang and Sridharan, 2002). Anderson and Narus (1996) explains that collaboration is one between independents but related companies to share their resources and their abilities to meet the needs of customers. Anthony (2000) defines the term collaboration is two or more companies share responsibility to exchange the spreading, management, implementation, and performance measurement information plans. Soosay (2008) concluded that the cooperation can be described as a reciprocal relationship type organization, in which participants agree with the investment of resources, along with achieving goals, sharing information, resources, rewards and responsibility as well as to make decisions and solve problems together. In briefly, SCC helps a business organization coordinating and operating efficiency including supply chain management, reducing costs and inventory, increasing the level of customers satisfaction (Holweg, 2005; Soosay, 2008; Suong, H.T.T, 2012; Whipple et al., 2007). 


\subsubsection{Contents of supply chain collaboration}

Goteborg and Sweden (2007), Lambert (1998) concluded that the relationships in the supply chain are mostly active vertically or horizontally way. Vertically relationship covers all of the relationships within the enterprises, between components in difference classes. Horizontal relationship includes relationships within a same class. A vertical chain completely connects the first provider in many ways to the final customer. Vertical alignment occurs when a central factors increase influence role to the other factors in many different classes. Vertical alignment is always directed at both the relationship between the manufacturer and the first supplier and between the manufacturers with the final customer (Christopher, 2005). There are three forms to build supply chain collaborations including vertical collaboration, horizontal collaboration and multi-dimensional cooperation (Backstrand and Safsten, 2006; Christopther, 1998; Mentzer, 2001; Togar and Sridharan, 2005).

\subsubsection{The level of supply chain collaboration}

According to Cohen and Roussen (2006), Jenny Backstrand (2007) the interaction in the supply chain including three main components or more, referred to as transaction activity, collaboration and links. Each level of interaction contains a continuum of the kind of relationship type, include the following forms: (i) The transaction is generally understood as the exchange or transfer of goods, services or financial to each other. A transaction relationship means the activity of exchanging discrete value, especially about price (Achrol, 1991). The commercial transactions that involved price negotiation when the relationship with suppliers is a rival relationship and the goal is to aim to increase the personal profit of a member in the chain; (ii) The cooperation form in general is like working together or cooperate with a partner to whom cannot connect immediately. In other word, cooperate is to act or work together or with other partner so that both can be beneficial. The types of collaborative relationships are rival cooperation or non-rival cooperation (Cox, 2001), partners (Webster, 1992; Mentzer and associates, 2000), and the cooperation between manufacturer and supplier (Cravens and Associates, 1996); (iii) Linking form is often viewed as the union of the two entities into one entity for a business progress between two actors, the affiliate relationship consists of vertical link (Webster, 1992), buy back and venture (Ellram, 1991), and full-ownership (Bengtsson et al., 1998) or merged (MacBeth and Ferguson, 1994).

\subsection{Factors affecting supply chain collaboration}

A vast supply network has a lot of interwoven connections, contain various contradictions between the subjects comes from a range of different factors (Simatupang and Sridharan, 2002). When focused on analysis the relationship between the components within the supply chain, research has shown nine important factors affecting the supply chain collaboration, as are summarized in table 1:

Table 1: Variables definition

\begin{tabular}{|c|c|c|}
\hline Variables & Definition & Authors \\
\hline \multicolumn{3}{|c|}{ Independent variables } \\
\hline Trust & $\begin{array}{l}\text { A positive belief, attitude, or expectation of one } \\
\text { party concerning the likelihood that the action } \\
\text { or outcomes of another will be satisfactory } \\
\text { (Andaleeb, 1992). This factor therefore affects } \\
\text { positively on sullply chain collaboration. }\end{array}$ & 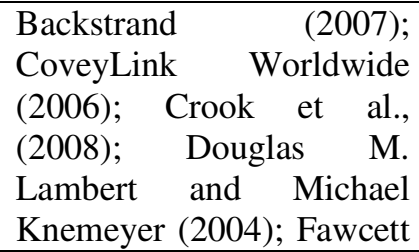 \\
\hline
\end{tabular}




\begin{tabular}{|c|c|c|}
\hline & & $\begin{array}{l}\text { et al., (2008); Fawcett et } \\
\text { al., (2011); Forslund and } \\
\text { Jonsson (2009); Fyneset et } \\
\text { al., (2005); Kwon and Suh } \\
\text { (2004); Nyaga et al., } \\
\text { (2010); Simatupang et al., } \\
(2004) ; \quad \text { Suong, H.T.T } \\
\text { (2012); Walter (2003); } \\
\text { Zacharia et al. (2009); }\end{array}$ \\
\hline Power & $\begin{array}{l}\text { When designing a supply chain and cooperating } \\
\text { with other companies, one has to consider the } \\
\text { other actor's size, impact, and status. If the } \\
\text { other actor is larger in size, has greater impact, } \\
\text { and higher status, it will have more power in } \\
\text { that relation (CoveyLink Worldwide, 2006; } \\
\text { Backstrand, 2007; Suong, H.T.T, 2012). With } \\
\text { greater power comes the ability to force a } \\
\text { weaker actor to make decisions that are merely } \\
\text { favorable for the powerful actor. The effect of } \\
\text { power in supply chains has in fact been pointed } \\
\text { out by several authors. }\end{array}$ & $\begin{array}{l}\text { McDonald et al., (1999); } \\
\text { Backstrand (2007); Joyce } \\
\text { and Mattew (2002); } \\
\text { Buttaney and Lawrence } \\
\text { (1988); Suong, H.T.T } \\
\text { (2012); Donald C. Mead } \\
\text { (1995); Butaney and } \\
\text { Lawrence (1988); Watson } \\
\text { (2001); Cox et al., (2004) }\end{array}$ \\
\hline Maturity & $\begin{array}{l}\text { Increased supply chain interaction maturity } \\
\text { leads to reduced uncertainty, and improved } \\
\text { business performance and is the best route to } \\
\text { follow to achieve competitive advantage. The } \\
\text { characteristics of process maturity are } \\
\text { predictability, capability, control, effectiveness, } \\
\text { and efficiency }\end{array}$ & $\begin{array}{l}\text { Childerhouse et al., (2003); } \\
\text { Backstrand (2007); Suong, } \\
\text { H.T.T (2012) }\end{array}$ \\
\hline Frequency & $\begin{array}{l}\text { Frequency refers to how often a transaction } \\
\text { occurs. More transactions suggests greater } \\
\text { routinization of interaction and is hence, an } \\
\text { implication/incitement to form a closer } \\
\text { relationship to make sure that transactions run } \\
\text { smoothly }\end{array}$ & $\begin{array}{l}\text { Ellarm (1991); } \quad \text { Sahay } \\
\text { (2003); Suong, } \quad \text { H.T.T } \\
\text { (2012); Cooper (1997) }\end{array}$ \\
\hline Distance & $\begin{array}{l}\text { Distance between the partners in the supply } \\
\text { chain refer to the geographical distance, the } \\
\text { culture distance and the organizational gap } \\
\text { between partners through the supply chain }\end{array}$ & $\begin{array}{l}\text { Cooper (1997); Suong, } \\
\text { H.T.T (2012) }\end{array}$ \\
\hline Culture & $\begin{array}{l}\text { Defined as a shared values and belief that can } \\
\text { help to understand organizational functioning } \\
\text { and provide behavioral norms.the collective } \\
\text { programming of the mind which distinguishes } \\
\text { the members of one group or category of people } \\
\text { from another. Differences in organisational or } \\
\text { social level, could create differences of opinion } \\
\text { or conflicts of interest (Tan et al., 2006) }\end{array}$ & $\begin{array}{l}\text { Tan et al., (2006); Jin and } \\
\text { Hong (2007); Suong, } \\
\text { H.T.T (2012); Stephen M. } \\
\text { Dent (2006) }\end{array}$ \\
\hline Strategy & $\begin{array}{l}\text { Collaborative planning refers to collaborations } \\
\text { among trading partners to develop various plans } \\
\text { such as production planning and scheduling, } \\
\text { new product development, inventory } \\
\text { replenishment, and promotions and }\end{array}$ & $\begin{array}{l}\text { Simatupang and Sridharan } \\
\text { (2005, 2008); Simatupang } \\
\text { et al., (2002); Suong, } \\
\text { H.T.T (2012); Stephen M. } \\
\text { Dent (2006); Manoj }\end{array}$ \\
\hline
\end{tabular}


International Journal of Managing Value and Supply Chains (IJMVSC) Vol. 6, No. 4, December 2015

\begin{tabular}{|l|l|l|}
\hline \multirow{1}{*}{ Policies } & $\begin{array}{l}\text { advertisement. Decision synchronization refers } \\
\text { to the process by which supply chain partners } \\
\text { orchestrate decisions in supply chain planning } \\
\text { and operations that optimize the supply chain } \\
\text { benefits (Manoj Hudnurkar et al., 2013). }\end{array}$ & Hudnurkar et al., (2013). \\
\hline Commitment & $\begin{array}{l}\text { Governmental intervention in business } \\
\text { activities. Local governments exert more direct } \\
\text { influences by implementing formal and } \\
\text { informal policies related to economic activity }\end{array}$ & $\begin{array}{l}\text { Beth Jenkins et al., (2008); } \\
\text { Suong, H.T.T (2012); Cai } \\
\text { et al., (2010) }\end{array}$ \\
\hline $\begin{array}{l}\text { Commitment refers to the willingness of trading } \\
\text { partners to exert effort on behalf of the } \\
\text { relationship and suggests a future orientation in } \\
\text { which firms attempt to build a relationship that } \\
\text { can be sustained in the face of unanticipated } \\
\text { problems (Porter et al., 1974). }\end{array}$ & $\begin{array}{l}\text { Walter (2003); Fynes et } \\
\text { al., Kons); Chen et al., } \\
(2004) ; \text { Nyaga et and Suh } \\
(2010) ; \text { Zacharia et al., } \\
(2009)\end{array}$ \\
\hline
\end{tabular}

Source: Summarized by author (2015).

\section{METHODOLOGY AND RESEARCH HYPOTHESES}

This research was done based on two methods: (1) qualitative research is conducted in order to construct, calibrate the components scale: the trust rate between the partners; The power of partner; The level of maturity of the relationship between partners; The frequency of transactions between partners; The distance between partners; The policy of the Government; Cultural cooperation, Partners cooperation strategy; Committed, (2) quantitative research aims to collect, analysis survey data, as well as testing the component scale, measuring the research theory model and the hypothesis.

Preliminary research is built and calibrated the scales and adds the observation variables through qualitative and quantitative methods. Preliminary qualitative research is done through expert group discussions with mechanical enterprises by the sampling method. The content of the discussions revolves around the of issues related to the factors that influence customer loyalty; Give out the research model for the discussion group to comment about the factors that affect the supply chain collaboration; give out the draft scale built up by the author group and corrected by the discussion group. After the exchange of ideas, the discussion group agreed with the model proposed by the author group. The discussion group is also recommended to calibrate some of the name of the scale components, and proposed to amend, add some convenience observation variables in Dong Nai province. From that, the research group has agreed about the factors that affect the supply chain collaboration research model, include: (1) the degree of trust between partners; (2) the power of partner; (3) the degree of maturity in the relationship between the partners; (4) the frequency of transactions between partners; (5) the distance between partners; (6) the policy of the government; (7) collaborative culture; (8) collaboration strategy of partners; (9) commitment. The scale of the research model included 35 observation variables measured by Likert scale 5 points with 1 - completely disagree to 5 - completely agree. Preliminary quantitative research is done by a survey with 40 samples from the mechanical business. The results showed that the Cronbach's Alpha coefficient has achieved 86.07\%, showed that the scales have high reliability. The formal research is done by sending direct survey questionnaires, direct phone and email as a convenience method to the mechanical enterprises in Ho Chi Minh 
City, Dong Nai and Binh Duong Province is divided by type, category, and area to ensure the representative of research sample.

The data after cleaning and the evaluate the normal distribution will be analyzed by SPSS and Smart PLS software to test the scale's quality, the relevance of the model and test the research hypotheses about the relationship between the dependent and independent variables in the research model.

Research assumptions including:

H1: The degree of trust between partners affects positively on the collaboration in supply chain of mechanical enterprises in vietnam

$\mathrm{H} 2$ : The power of partners affects positively on the collaboration in supply chain of mechanical enterprises in vietnam

H3: The degree of maturity in the relationship between the partners affects positively on the collaboration in supply chain of mechanical enterprises in vietnam

H4: The frequency of transactions between partners affects positively on the collaboration in supply chain of mechanical enterprises in vietnam

H5: The distance between partners affects positively on the collaboration in supply chain of mechanical enterprises in vietnam

H6: The policy of the government affects positively on the collaboration in supply chain of mechanical enterprises in vietnam

H7: The collaborative culture affects positively on the collaboration in supply chain of mechanical enterprises in vietnam

H8: The collaboration strategy of partners affects positively on the collaboration in supply chain of mechanical enterprises in vietnam

H9: The commitment affects positively on the collaboration in supply chain of mechanical enterprises in Vietnam

\section{RESULTS AND DISCUSSION}

Datasets are cleaned after 205 samples which enough for the conditions of factor analysis to explore the structure and linear model (Bagozzi and Yi, 1988; Hair et al., 2010, 2011, 2013; Henseler, 2010; Henseler and Sarstedt, 2013; Hoyle, 1995; Jackson, 2001, 2003; Kline, 1998; Marcoulides and Saunder, 2006; Ringle et al., 2005). Characteristics of the sample are categorized into 4 groups which consisting of (i) the type of enterprises (ii) enterprise size, (iii) industries and (iv) national origin (table 2).

Table 2: Characteristics of study sample

\begin{tabular}{|c|c|}
\hline Variables & Attributes \\
\hline Enterprises by type & Enterprise with foreign capital $=61.97 \% ;$ Domestic enterprise $=$ \\
& $38.03 \%$. \\
Enterprises by size & Super small = $18.22 \%$; small and medium $=70.56 \% ;$ Large enterprise \\
& $=11.22 \%$ \\
Enterprises by & Engine manufacture, parts, assemble parts cluster $=47.1 \% ;$ Repair $=$ \\
Industries & $34.68 \% ;$ domestic appliance $=18.22 \%$ \\
Enterprises by & Vietnam = 36.03\%; France $=5.37 \% ;$ Japan $=16 \% ;$ Korea $=14.73 \% ;$ \\
national origin & Taiwan $=13.5 \% ;$ China $=7 \% ;$ Others $=7.37 \%$ \\
\hline
\end{tabular}


International Journal of Managing Value and Supply Chains (IJMVSC) Vol. 6, No. 4, December 2015

\section{Reliability}

The reliability and validity of indicators in the model are tested by system of criteria and is presented visually in table 3 . Individual factor reliability was assessed by examining the loadings $(>0.50)$ of respective factors on their respective latent constructs (Hulland, 1999). The composite factor reliability coefficients of the constructs ranged from 0.7401 to 0.9175 , which met the standard of 0.70 as suggested by Fornell and Larcker (1981).

Table 3: Summarizes the results of testing scale

\begin{tabular}{|c|c|c|c|c|c|}
\hline $\begin{array}{c}\text { Latent } \\
\text { variables }\end{array}$ & Indicator & $\begin{array}{c}\text { Factor } \\
\text { loadings }\end{array}$ & $\begin{array}{l}\text { Indicator } \\
\text { reliability } \\
\left(\text { Loadings }^{2}\right)\end{array}$ & $\begin{array}{l}\text { Composite } \\
\text { reliability }\end{array}$ & $\begin{array}{c}\text { Average } \\
\text { Variance } \\
\text { Extracted }\end{array}$ \\
\hline \multirow{5}{*}{$\begin{array}{c}\text { Collaboration } \\
\text { (Y) }\end{array}$} & Col1 & 0.8119 & 0.6592 & \multirow[t]{5}{*}{0.9175} & \multirow[t]{5}{*}{0.6898} \\
\hline & Col2 & 0.8276 & 0.6849 & & \\
\hline & Col3 & 0.8298 & 0.6886 & & \\
\hline & Col4 & 0.8478 & 0.7187 & & \\
\hline & Col5 & 0.8354 & 0.6978 & & \\
\hline \multirow[t]{3}{*}{ Commitment } & Com1 & 0.7759 & 0.6020 & \multirow[t]{3}{*}{0.7401} & \multirow[t]{3}{*}{0.5430} \\
\hline & Com2 & 0.8512 & 0.7245 & & \\
\hline & Com3 & 0.8230 & 0.6773 & & \\
\hline \multirow[t]{3}{*}{ Culture } & Cul1 & 0.1908 & 0.0364 & \multirow[t]{3}{*}{0.8884} & \multirow[t]{3}{*}{0.7992} \\
\hline & Cul2 & 0.8912 & 0.7942 & & \\
\hline & Cul3 & 0.8936 & 0.7985 & & \\
\hline \multirow{3}{*}{ Frequency } & Fre1 & 0.7104 & 0.5046 & \multirow[t]{3}{*}{0.8365} & \multirow[t]{3}{*}{0.6323} \\
\hline & Fre2 & 0.8858 & 0.7846 & & \\
\hline & Fre3 & 0.7794 & 0.6074 & & \\
\hline \multirow[t]{4}{*}{ Maturity } & Mat1 & 0.7616 & 0.5800 & \multirow[t]{4}{*}{0.8424} & \multirow[t]{4}{*}{0.5722} \\
\hline & Mat2 & 0.7830 & 0.6131 & & \\
\hline & Mat3 & 0.7565 & 0.5723 & & \\
\hline & Mat4 & 0.7233 & 0.5231 & & \\
\hline \multirow[t]{3}{*}{ Policy } & Pol1 & 0.7582 & 0.5748 & \multirow[t]{3}{*}{0.7825} & \multirow[t]{3}{*}{0.5521} \\
\hline & Pol2 & 0.8185 & 0.6699 & & \\
\hline & Pol3 & 0.6419 & 0.4120 & & \\
\hline \multirow[t]{4}{*}{ Power } & Pow1 & 0.4075 & 0.1667 & \multirow[t]{4}{*}{0.8170} & \multirow[t]{4}{*}{0.5425} \\
\hline & Pow2 & 0.7959 & 0.6334 & & \\
\hline & Pow3 & 0.8567 & 0.7339 & & \\
\hline & Pow4 & 0.7979 & 0.6366 & & \\
\hline \multirow[t]{3}{*}{ Strategy } & Stra1 & 0.8186 & 0.6701 & \multirow[t]{3}{*}{0.8917} & \multirow[t]{3}{*}{0.7322} \\
\hline & Stra2 & 0.8898 & 0.7917 & & \\
\hline & Stra3 & 0.8588 & 0.7375 & & \\
\hline \multirow[t]{4}{*}{ Trust } & Tru1 & 0.7666 & 0.5876 & \multirow[t]{4}{*}{0.8867} & \multirow[t]{4}{*}{0.6619} \\
\hline & Tru2 & 0.8311 & 0.6907 & & \\
\hline & Tru3 & 0.8144 & 0.6632 & & \\
\hline & Tru4 & 0.8402 & 0.7059 & & \\
\hline \multirow[t]{3}{*}{ Distance } & Dis1 & 0.7773 & 0.6041 & 0.8407 & 0.6382 \\
\hline & Dis2 & 0.8560 & 0.7327 & & \\
\hline & Dis3 & 0.7620 & 0.5806 & & \\
\hline
\end{tabular}




\section{Convergent Validity}

Fornell and Larcker (1981) suggested that convergent validity of scales is established in the condition of the variance extracted value exceeds 0.50 . Results indicated that the variance extracted for ten variables ranged from 0.5425 to 0.7332 .

\section{Discriminant Validity}

Discriminant validity was assessed by the test provided by Fornell and Larcker (1981) in which the pair-wise correlations between factors obtained were compared with the variance extracted estimates for the constructs making up each possible pair. The Discriminate validity is adequate when constructs have an AVE loading greater than 0.5 meaning that at least $50 \%$ of measurement variance was captured by the construct (Chin, 1998). In addition, discriminate validity is confirmed if the diagonal elements are significantly higher than the off-diagonal values in the corresponding rows and columns. The diagonal elements are the square root of the AVE score for each construct. These values are shown in Table 4.

Table 4: Fornell-Larcker Criterion Analysis for Checking Discriminant Validity

\begin{tabular}{|c|c|c|c|c|c|c|c|c|c|c|}
\hline & Collaboration & Commitment & Culture & Distance & Frequency & Maturity & Policies & Power & Strategy & Trust \\
\hline Collaboration & 0.8173 & & & & & & & & & \\
\hline Commitment & 0.5306 & 0.7368 & & & & & & & & \\
\hline Culture & 0.7167 & 0.3555 & 0.7995 & & & & & & & \\
\hline Distance & 0.6043 & 0.3256 & 0.4690 & 0.8136 & & & & & & \\
\hline Frequency & 0.6051 & 0.3159 & 0.4973 & 0.4021 & 0.7952 & & & & & \\
\hline Maturity & 0.5987 & 0.2903 & 0.4752 & 0.3324 & 0.4138 & 0.7564 & & & & \\
\hline Policies & 0.5065 & 0.2106 & 0.3522 & 0.3625 & 0.2587 & 0.2757 & 0.8305 & & & \\
\hline Power & 0.6550 & 0.3219 & 0.4939 & 0.3923 & 0.3826 & 0.4464 & 0.2885 & 0.7432 & & \\
\hline Stratery & 0.6543 & 0.3847 & 0.4038 & 0.3557 & 0.3666 & 0.3838 & 0.3386 & 0.4235 & 0.7365 & \\
\hline Trust & 0.4692 & 0.3244 & 0.3661 & 0.2924 & 0.2200 & 0.3379 & 0.3848 & 0.2818 & 0.2516 & 0.8563 \\
\hline
\end{tabular}

\section{Hypothesis Testing}

The $\mathrm{R}^{2}$ measures a construct's percent variation that is explained by the model (Wixom and Watson, 2001). The coefficient of the determination, $\mathrm{R}^{2}$ equal 0.839 for the Collaboration endogenous latent variable. This mean that the nine latent variables (1) the degree of trust between partners; (2) the power of partner; (3) the degree of maturity in the relationship between the partners; (4) the frequency of transactions between partners; (5) the distance between partners; (6) the policy of the government; (7) collaborative culture; (8) collaboration strategy of partners and (9) commitment) moderately explain $83.9 \%$ of the variance in Collaboration. Results of testing the hypotheses in the research model showed that compared with initial expectations all of nine relationships are acceptable.

In the nine factors affecting the results supply chain collaboration, the impact of Strategy are strongest $(\beta=0.227)$, followed by Culture $(\beta=0.221)$, followed by Power $(\beta=0.189)$, Frequency $(\beta=0.146)$, Distance $(\beta=0.140)$, Commitment $(\beta=0.128)$, the impact of Policies and Maturity $(\beta=0.129)$ and is finally the impact of Trust $(\beta=0.078)$. The nine factors moderately strong predictor of Collaboration in supply chain of mechanical enterprises. The quality of the structural model for each endogenous block can be assessed by the Redundancy index (Chantelin et al., 2002). Because of the objective of PLS is to maximize variance explained 
rather than fit, therefore predictionoriented measures such as $\mathrm{R}^{2}$ are used to evaluate PLS models (Chin, 1998). Chin (1998) recommended that a bootstrapping procedure using 1000 sub samples was performed to evaluate the statistical significance of each path coefficient. Table 5 shows hypothesized path coefficients along with their bootstrap values and T' values.

Table 5: Showing path coefficients along with their bootstrap values, T-Statistics

\begin{tabular}{|c|c|c|c|c|c|}
\hline & $\begin{array}{c}\text { Original } \\
\text { Sample }\end{array}$ & $\begin{array}{c}\text { Sample } \\
\text { Mean }\end{array}$ & $\begin{array}{c}\text { Standard } \\
\text { Deviation }\end{array}$ & $\begin{array}{c}\text { Standard } \\
\text { Error }\end{array}$ & T-Statistics \\
\hline Strategy $\rightarrow$ Collaboration & 0.2273 & 0.2236 & 0.0389 & 0.0389 & 5.867 \\
\hline Culture $\rightarrow$ Collaboration & 0.2214 & 0.2197 & 0.0508 & 0.0508 & 4.239 \\
\hline Power $\rightarrow$ Collaboration & 0.1885 & 0.1869 & 0.0400 & 0.0400 & 4.699 \\
\hline Frequency $\rightarrow$ Collaboration & 0.1459 & 0.1460 & 0.0362 & 0.0362 & 4.002 \\
\hline Distance $\rightarrow$ Collaboration & 0.1398 & 0.1412 & 0.0422 & 0.0422 & 3.361 \\
\hline Commitment $\rightarrow$ Collaboration & 0.1279 & 0.1259 & 0.0330 & 0.0330 & 3.850 \\
\hline Policies $\rightarrow$ Collaboration & 0.1189 & 0.1177 & 0.0355 & 0.0355 & 3.353 \\
\hline Maturity $\rightarrow$ Collaboration & 0.1194 & 0.1202 & 0.0382 & 0.0382 & 3.143 \\
\hline Trust $\rightarrow$ Collaboration & 0.0775 & 0.0775 & 0.0384 & 0.0348 & 2.226 \\
\hline
\end{tabular}

In this study, 5000 times analyzed repeatly with Bootstrap method was conducted in order to test the stability of the estimates for parameters. The results show that the difference from the initial estimate method does not have a huge difference compared to the estimates by bootstrap methods. All the difference in the estimates is not significant statistically. So the model estimates of reliability are guaranteed for the verification of model assumptions in this research.

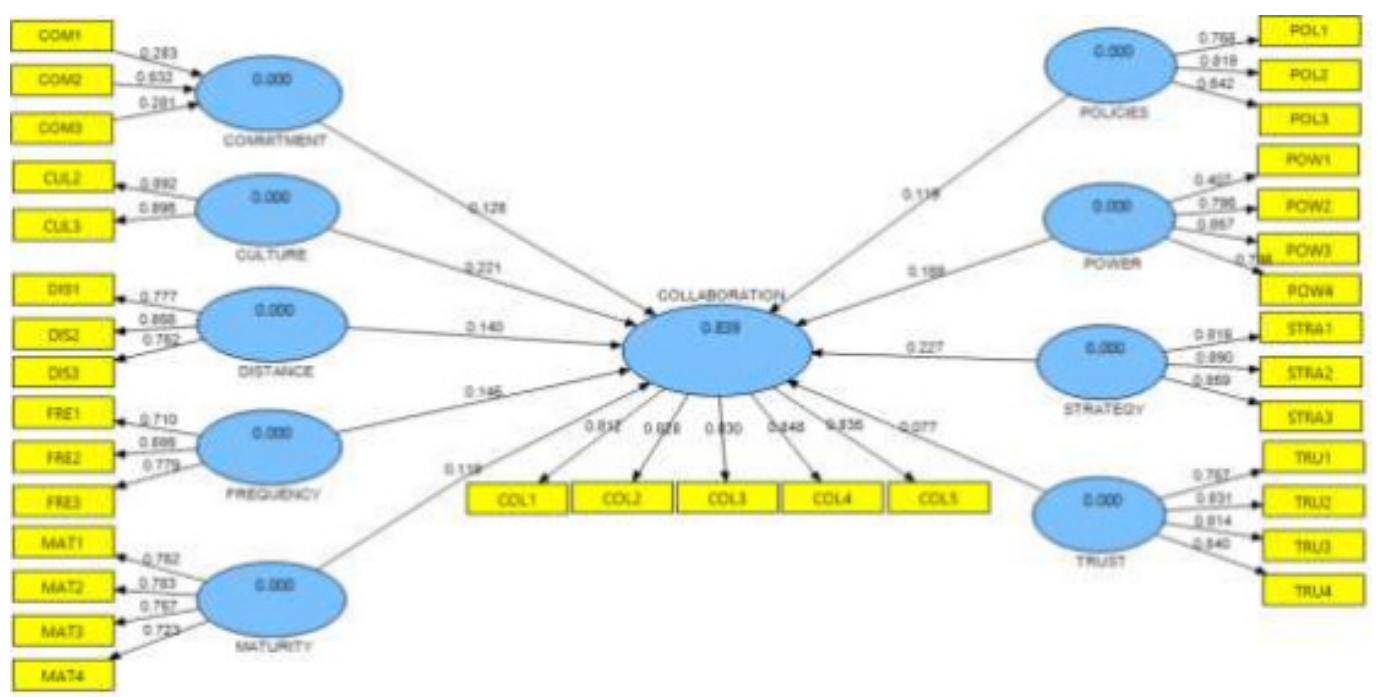

Figure 2: Structural equation modelling

The evaluation of PLS model is based on prediction-oriented measures that are nonparametric (Chin, 1998). The PLS structural model is mainly evaluated by Goodness-of-Fit (GoF) (Tenenhaus et al., 2005) and by using the Stone-Geiser Q-square test for predictive relevance (Stone, 1974; and Geiser, 1975). Goodness-of-Fit (GoF) was employed to judge the overall fit of the model, GoF, which is the geometric mean of the average communality and the average $\mathrm{R}^{2}$, represents an index for validating the PLS model generally, as looking for a compromise between the performance of the measurement and the structural model, respectively. This model gets the GoF index was 0.7422 (table 6). 
Table 6: Showing Model Evaluation Results

\begin{tabular}{|c|l|l|l|l|l|}
\hline Block & \multicolumn{1}{|c|}{$\mathrm{R}^{2}$} & \multicolumn{1}{|c|}{ Communality } & $\mathrm{H}^{2}$ & Redundancy & $\mathrm{F}^{2}$ \\
\hline Collaboration & 0.8393 & 0.6898 & -0.2388 & 0.0817 & 0.3383 \\
\hline Strategy & & 0.7332 & -0.3492 & & \\
\hline Culture & & 0.7992 & -0.4472 & & \\
\hline Power & & 0.6425 & -0.3645 & & \\
\hline Frequency & & 0.6323 & -0.3373 & & \\
\hline Distance & & 0.6382 & -0.3672 & & \\
\hline Commitment & 0.6497 & -0.3647 & & \\
\hline Policies & & 0.5521 & -0.4181 & & \\
\hline Maturity & & 0.5722 & -0.3372 & & \\
\hline Trust & 0.6619 & -0.2769 & & \\
\hline Average & 0.8393 & 0.6571 & & 0.0817 & \\
\hline GoF $=\sqrt{\text { average }} \mathrm{R}^{2} \mathrm{x}$ average communality $=\sqrt{ } 0.0 .5508=0.7422$ (Tenenhaus et al., 2005) \\
\hline Note: $\mathrm{H}^{2}=\mathrm{CV}$-Communality Index, $\mathrm{F}^{2}=\mathrm{CV}-$ Redundancy Index \\
\hline
\end{tabular}

Results reveal that for this model all the blocks had high values of $\mathrm{H}^{2}$, ranging from -0.4472 to 0.2388 and $\mathrm{F}^{2}$ ranging from 0.3383 . All $\mathrm{H}^{2}$ and $\mathrm{F}^{2}$ values were positive (above threshold level), meaning that the model had acceptable predictive relevance.

\section{Policy implications for the development of supply chain collaboration of mechanical enterprises in Vietnam in the context of international economic integration}

Empowering and the capacity of enterprises to consolidate power for the partners: Build up enterprises image to enhance the degree of trust in their dealings with partners: through the implementing measures, enterprises maintain and develop their capacity. If the enterprise always focus on developing the above aspects, its capacity will have high evaluation and through that the enterprises are eligible to consolidate and increase its power to partners in order to attract the collaboration voluntarily as well as pressure the partners to be proactive in cooperation with enterprises within the chain. Affirm the brand value in the development of Vietnam mechanical industry with the promotion of applying technology in business, improve production technology and continue to focus on improving the quality of the product, be active in the material sources.

The producers must regularly maintain the trading activities with partners in order to enhance the level of maturity, making convenience to promoting collaborating relationship: through the relation between the enterprises with partners in the industry, reach the maturity in the relationship means that enterprises have the ability to predict supply and demand and can effective control partner through aspects such as the habits, customs transactions regarding the method of payment, conditions of delivery, the method of delivery. That will help the business relations of enterprises to be effective.

The producers must proactively enhance the frequency of transactions between the actors in the supply chain: enhances the frequency means to increase the number of transactions between enterprise and partner in the chain. Once the transaction takes place regularly, it will reinforce the level of cooperation between enterprise and partner.

Plan an appropriate cooperation strategy with new business condition to: first of all, enterprises in the industry have to identify their goals when participating in the transactions. To determine this goal, enterprises will analyze the benefits from economic and financial that they will achieve. Merged and incorporated enterprises can take place with difference scale and forms based on the structure of the enterprises, purpose, and the relationship between the parties. 
Recommendations for the Government and other authorities: Need to enact legal soon for the enterprises to be convenience in business activities.

Recommendations for mechanical industry association: The Association must be the real bridge for the enterprises in the industry to talk, share information as well as feedback the information about the obstacles, hardship of the enterprise during the business process. The Association will certainly be the playground of any company in the industry despite its scope like. With that, the Association will truly become a forum for the enterprises to share information with each other as well as getting information to bind together, create the base for the enterprises to increase the cooperation to grow together. At the same time the Association will really become a bridge of the enterprises, reflect their distress to the Government Administration in time as the implementation.

\section{CONCLUSION}

This research bases on the survey data of 205 mechanical enterprises in Ho Chi Minh city, Dong Nai anh Binh Duong province in the Southeast region of Vietnam and through econometric models, research results have shown that there are nine factors that affect the supply chain collaboration, included (1) trust between partners, (2) power of partners (3) level of maturity in collaboration, (4) transactions frequency, (5) distance between partners, (6) collaboration culture, (7) collaboration strategy, (8) policies of government and (9) commitment of partners. Therefore it need to have measure to improve in turn or in sync the nine factors that were calculated and calibrated.

\section{ACKNOWLEDGEMENTS}

The authors would like to thank everyone, just everyone!

\section{REFERENCES}

[1] Achrol, R. S. (1997), "Changes in the theory of inter-organizational relations in marketing: toward a network paradigm", Journal of the Academy of Marketing Science, 25 (1): 56-71.

[2] Andaleeb (1992), "The trust concept: research issues for channel of distribution", Research in Marketing, Vol. 11, 1-34.

[3] Anderson, J. C. and Narus, J. A. (1996), "Rethinking distribution: adaptive channels", Harvard Business Review, 74(4), 20-38.

[4] Anthony, T. (2000), "Supply chain collaboration: success in the new internet economy", Achieving supply chain excellence through technology, 2, 41-44.

[5] Barratt, M. (2004), "Understanding the meaning of collaboration in the supply chain", Supply Chain Management: An International Journal, 9(1), 30-42.

[6] Backstrand, J. and Safsten, K. (2005), Review of supply chain collaboration levels and types, Proceedings from the 1st International Conference on Operations and Supply Chain Management: OSCM 2005, Bali, Indonesia.

[7] Backstrand, J. and Safsten, K. (2006), Supply Chain Interaction - Market requirements affecting the level of interaction, Proceedings from the 15th Annual IPSERA Conference 2006, San Diego, USA.

[8] Christopher, M. (2005), Logistics and Supply chain management - Creating Value-adding Network, 3rd edition, Prentice Hall.

[9] Cai, S., Jun, M., and Yang, Z. (2010), "Implementing supply chain information integration in China: The role of institutional forces and trust", Journal of Operations Management, 28(3), 257268.

[10] Cao M. and Zhang Q. (2011), "Supply chain collaboration: Impact on collaborative advantage and firm performance", Journal of Operations Management, 29(3).163-180. 
International Journal of Managing Value and Supply Chains (IJMVSC) Vol. 6, No. 4, December 2015

[11] Chen, J.V., Yen, D.C., Rajkumar, T.M., and Tomochko, N.A. (2011), "The antecedent factors on trust and commitment in supply chain relationships", Computer Standards and Interface, 33(3), 262-270.

[12] Cooper, M. C., Lambert, D. M. and Pagh, J. D. (1997), "Supply Chain Management: More than a New Name for Logistics", International Journal of Logistics Management. 8(1), 1-14.

[13] Crook et al., (2008), "Antecedents and Outcomes of Supply Chain Effectiveness: An ExploratoryInvestigation”, Journal of Managerial Issues, 20 (2), 161-177.

[14] Douglas M. Lambert, Margaret A. Emmelhainz, and John T. Gardner (2004), "Supply chain partnerships: Model validation and implementation", Journal of Quality Management, Vol. 25, No. 2.

[15] Ekkprawatt Phong-arjarn and Chawalit Jeenanunta (2011), "Exploring Supply Chain collaboration in Thai Major Industries", Naresuan University Journal.

[16] Ellram, L. M. (1991), "Supply Chain Management: The Industrial organisation perspective", International Journal of Physical Distribution and Logistics Management, 21(1), 13-22.

[17] Fynes et al., (2005), "The impact of supply chain relationship quality on quality performance", Int. J. Production Economics, 96 (3), 339-354.

[18] Fawcett, Stanley E., Gregory M. Magnan, and Matthew W. McCarter (2008), “A three-stage implementation model for supply chain collaboration”, Journal of Business Logistics, 29(1), 93112.

[19] Handfield and Bechtel (2002), "The role of trust and relationship structure in improving supply chain responsiveness", Industrial Marketing Management.

[20] Harland, C. M. (1996), "Supply Chain Management: Relationships, Chains and Networks", British Journal of Management, (7), 63-80.

[21] Holweg, M., Disney, S., Holmstrom, J. and Smros, J. (2005), "Supply chain collaboration: making sense of the strategy continuum”, European Management Journal, 23(2), 170-181.

[22] Suong, H.T.T (2012), Research of factors affecting the supply chain collaboration in furniture, Case Study: Southeast in Vietnam, PhD Thesis.

[23] Jean-Marc Frayret and Sophie D'Amours (2008), Measurement and Determinants of Supply Chain Collaboration.

[24] Kahn, K. B. and Mentzer, J. T. (1996), "Logistics and interdepartmental integration", International Journal of Physical Distribution and Logistics Management, 26(8) pp. 6-14.

[25] Kwon G and Suh T. (2004), "Factors Affecting the Level of Trust and Commitment in Supply Chain Relationship", Journal of Supply Chain Management, 40 (2). 4-14.

[26] Lambert, D. M., Cooper, M. C. and Pagh, J. D. (1998), "Supply Chain Management: Implementation Issues and Research Opportunities", International Journal of Logistics Management, 9(2), 1-19.

[27] Manoj Hudnurkar et al., (2013), "Factors Affecting Collaboration in Supply Chain: A Literature Review", Procedia - Social and Behavioral Sciences, Volume 133, 189-202.

[28] McDonald Frank (1999), “The Importance of Power in Partnership Relationships", Journal of General Management.

[29] Mentzer, J. T. (2001), Managing Supply Chain Collaboration.

[30] Tan, E.N., Smith, G., and Saad, M. (2006), "Managing the global supply chain: a SME perspective", Production Planning and Control, 17 (3), 238-246.

[31] Porter, L., Steers, R., Mowday, R., and Boulian, P. (1974), "Organizational commitment, job satisfaction, and turnover among psychiatric technicians”, Journal of Applied Psychology, 59, 603-609.

[32] Simatupang, T. M. and Sridharan, R. (2005), “The Collaboration Index: a Measure for Supply Chain Collaboration", International Journal of Physical Distribution andLogistics Management, 35(1), 44-62.

[33] Samaddar, S., Nargundkar, S., and Daley, M. (2006), "Inter-organizational information sharing: The role of supply network configuration and partner goal congruence", European Journal of Operational Research, 174(2), 744-765.

[34] Soosay, C. A., Hyland, P. W. and Ferrer, M. (2008), Supply chain collaboration capabilities for continuous innovation.

[35] Togar M. Simatupang, Ramaswami Sridharan (2005), "The collaboration index: a measure for supply chain collaboration", International Journal of Physical Distribution and Logistics Management, Vol. 35, $44-62$. 
International Journal of Managing Value and Supply Chains (IJMVSC) Vol. 6, No. 4, December 2015

[36] Vereeke, A., S., Muylle. (2006), "Performance improvement thought supply chain collaboration in Europe", International Journal of Operation and Production Management, 26(11), 1176-1198.

[37] Walter A. (2003), "Relationship-specific factors influencing supplier involvement in customer new product development", Journal of Business Research, 56(9), 721-733.

[38] Whipple, J.M. and Russell, D. (2007), "Building supply chain collaboration: a typology of collaborative approaches", International Journal of Logistics Management, 18(2), 174-196.

\section{Authors}

Luu Tien Dung: Lecturer-Researcher at Lac Hong University, University of Economics and Law - Ho Chi Minh City, Vietnam. PhD in Economics, Master in Social Science, B.A in International Economics. Main research areas: Development economics, Agriculture Economics, Economics applied in Business Administration.

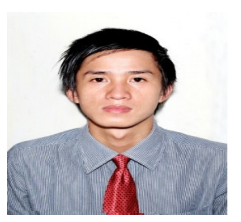

